Atmos. Chem. Phys., 13, 4279-4289, 2013

www.atmos-chem-phys.net/13/4279/2013/

doi:10.5194/acp-13-4279-2013

(C) Author(s) 2013. CC Attribution 3.0 License.

\title{
The 2007-2011 evolution of tropical methane in the mid-troposphere as seen from space by MetOp-A/IASI
}

\author{
C. Crevoisier ${ }^{1}$, D. Nobileau ${ }^{1}$, R. Armante ${ }^{1}$, L. Crépeau ${ }^{1}$, T. Machida ${ }^{2}$, Y. Sawa ${ }^{3}$, H. Matsueda ${ }^{3}$, T. Schuck ${ }^{4}$, \\ T. Thonat $^{1}$, J. Pernin ${ }^{1}$, N. A. Scott ${ }^{1}$, and A. Chédin ${ }^{1}$ \\ ${ }^{1}$ Laboratoire de Météorologie Dynamique, CNRS, UMR8539, IPSL, Ecole Polytechnique, 91128 Palaiseau Cedex, France \\ ${ }^{2}$ Center for Global Environmental Research, National Institute for Environmental Studies, Tsukuba, Japan \\ ${ }^{3}$ Geochemical Research Department, Meteorological Research Institute, Tsukuba, Japan \\ ${ }^{4}$ Atmospheric Chemistry Division, Max Planck Institute for Chemistry, Mainz, Germany
}

Correspondence to: C. Crevoisier (cyril.crevoisier@1md.polytechnique.fr)

Received: 13 July 2012 - Published in Atmos. Chem. Phys. Discuss.: 12 September 2012

Revised: 28 February 2013 - Accepted: 16 March 2013 - Published: 25 April 2013

\begin{abstract}
Since July 2007, monthly averages of midtropospheric methane have been retrieved in the tropics over land and sea, by day and night, from IASI onboard MetOpA, yielding a complete view of the geographical distribution, seasonality and long-term tendency of methane in the mid-troposphere. Retrieved methane displays a clear seasonal cycle of $\sim 25 \mathrm{ppbv}$ in the northern tropics, with a maximum in November and a minimum in April-May, a more complex cycle of $\sim 15 \mathrm{ppbv}$ in the southern tropics, and a south-to-north latitudinal variation of $\sim 30 \mathrm{ppbv}$ - in good agreement with regular aircraft measurements of the CONTRAIL program. Comparisons with CARIBIC aircraft measurements made at $\sim 11 \mathrm{~km}$ yield an averaged difference between collocated IASI estimates and CARIBIC measurements of $7.2 \mathrm{ppbv}$ with a standard deviation of $13.1 \mathrm{ppbv}$. Comparisons with aircraft measurements made above $6 \mathrm{~km}$ during five HIPPO campaigns give an averaged difference between collocated IASI estimates and HIPPO measurements of 5.1 ppbv with a standard deviation of 16.3 ppbv. These comparisons show that IASI captures well the evolution of mid-tropospheric methane. In particular, in 2007 and 2008, IASI shows an increase of mid-tropospheric methane in the tropical region of $9.5 \pm 2.8$ and $6.3 \pm 1.7 \mathrm{ppbv} \mathrm{yr}^{-1}$, respectively - in excellent agreement with the rate of increase measured at the surface after almost a decade of nearzero growth. IASI also indicates a slowing down of this increase in the following years to $\sim 2 \mathrm{ppbv} \mathrm{yr}^{-1}$, with the highest increase in 2010. Assuming that the recent evolution of methane is mostly due to an increase in surface emissions,
\end{abstract}

IASI might indicate a decrease in tropical wetland emissions for the period 2009-2011 compared to 2007-2008, in agreement with decreasing tropical precipitation over this period, together with an increase in biomass burning emissions in 2010 in the southern tropics.

\section{Introduction}

Methane $\left(\mathrm{CH}_{4}\right)$ is the third most important greenhouse gas in the atmosphere, after water vapor and $\mathrm{CO}_{2}$, and is responsible for about $20 \%$ of the total radiative forcing by long-lived greenhouse gases (Hofmann et al., 2006). On a per-molecule basis, its global warming potential is even greater than for $\mathrm{CO}_{2}$ (IPCC, 2007). Moreover, methane plays a significant role in tropospheric chemistry through its removal of $\mathrm{OH}$ that increases its radiative forcing by indirectly increasing the radiative forcing of ozone and stratospheric water vapor. There is therefore a considerable interest in monitoring the evolution of atmospheric methane to better characterize its atmospheric budget and infer how it might evolve in the future.

The average concentration of atmospheric methane stems, through the mass balance equation, from the sum of all its sources and sinks and mostly reflects the balance between emission from the surface and destruction by $\mathrm{OH}$ in the troposphere. Methane is emitted at the surface by several natural and anthropogenic sources (Matthews and Fung, 1987; Bousquet et al., 2011). The largest source of methane comes from natural wetlands (Ringeval et al., 2010), mostly 
in the tropical region, but also at mid-to-high northern latitudes. Major anthropogenic sources include coal mining, natural gas losses, solid waste burning and also emissions from ruminant animals, rice paddies and biomass burning. Altogether, global emissions of methane range from 500 to $600 \mathrm{Tg} \mathrm{CH}_{4} \mathrm{yr}^{-1}$ (Denman et al., 2007). The partitioning of the global emissions between these various sources, as well as the impact of human activities on these sources, remain poorly known. Most of the emitted $\mathrm{CH}_{4}$ is destroyed in the atmosphere by the chemical reaction with tropospheric $\mathrm{OH}$, which accounts for $428-511 \mathrm{Tg} \mathrm{CH}_{4} \mathrm{yr}^{-1}$, and happens predominantly in the tropics (Fung et al., 1991; Denman et al., 2007; Spivakovsky et al., 2012).

Over the last decades, the atmospheric methane burden has undergone a series of significant changes. Its global average has more than doubled since the beginning of the industrial era (Cunnold et al., 2002), with a persistent increase since the 1970s (Dlugokencky et al., 1994), but the rate of increase in $\mathrm{CH}_{4}$ has been steadily decreasing since the late 1980s (Steele et al., 1992), reaching a near-zero increase from 1999 to 2006 (Dlugokencky et al., 2003; Worthy et al., 2009). Several hypotheses have been proposed to explain the atmospheric methane budget and its interannual and long-term variations: changes in various sources (for instance wetland emissions (Mikaloff-Fletcher et al., 2004; Bousquet et al., 2006), anthropogenic emissions (Dlugokencky et al., 1994), wild fires (Langenfelds et al., 2002)) and changes in $\mathrm{OH}$ photochemistry (Dentener et al., 2003; Prinn et al., 2005). From the end of 2006 or beginning of 2007 , a renewed growth of atmospheric $\mathrm{CH}_{4}$ has been observed by surface networks until the most recent measurements (Rigby et al., 2008; Dlugokencky et al., 2009; Terao et al., 2011), potentially stemming from a combination of a slight change in $\mathrm{OH}$ and increased emissions in northern high- and low-latitude regions (Bousquet et al., 2011). This increase has also been observed in 2007-2009 on total columns of methane retrieved, mostly over land, from near-infrared observations by the SCIAMACHY (SCanning Imaging Absorption spectroMeter for Atmospheric CHartographY) instrument on board the European Space Agency's ENVISAT (environmental research satellite) (Frankenberg et al., 2011).

Although the current surface atmospheric measurement networks allow monitoring the average evolution of atmospheric methane, it is not sufficient to fully describe the global atmospheric methane burden and to resolve regional methane surface fluxes. This is particularly true in the tropics: despite the fact that natural tropical sources are believed to be the largest methane sources (natural wetlands, rice paddies in Asia, biomass burning), their emissions are not well captured by the current surface stations networks because of its sparseness and because of intense convective mixing, which dilutes the signal of surface fluxes in the air column, causing a smaller sensitivity of surface stations to $\mathrm{CH}_{4}$ sources (Bousquet et al., 2011). Another major flaw in the current network is that measurements have mostly been made at the surface and therefore lack the information in the free troposphere despite the major role this part of the atmosphere plays in the atmospheric budget of methane through tropospheric chemistry. This is particularly true in the tropics, where more than half of the total destruction of $\mathrm{CH}_{4}$ by OH occurs (Fung et al., 1991). Here we present more than 4 years of mid-tropospheric methane derived from the Infrared Atmospheric Sounding Interferometer (IASI) over the tropics, spanning July 2007-December 2011, that we compare to aircraft measurements and from which we infer characteristics of tropospheric methane and its most recent evolution.

\section{Method and data}

\subsection{IASI}

IASI, developed by CNES in collaboration with EUMETSAT, is a Fourier transform spectrometer based on a Michelson interferometer coupled to an integrated imaging system that measures infrared radiation emitted from the Earth. IASI provides 8461 spectral samples, aligned in three bands between $645.00 \mathrm{~cm}^{-1}$ and $2760.00 \mathrm{~cm}^{-1}(15.5 \mu \mathrm{m}$ and $3.63 \mu \mathrm{m}$ ), with a spectral resolution of $0.50 \mathrm{~cm}^{-1}$ after apodization and a spectral sampling interval of $0.25 \mathrm{~cm}^{-1}$. IASI was launched on October 2006 onboard the European MetOp-A platform and declared operational in July 2007. Since then it has been providing water vapor and temperature soundings for operational meteorology, while observing simultaneously a whole suite of trace gases (Hilton et al., 2012).

\subsection{Methane retrieval process}

As described in details in Crevoisier et al. (2009a), the retrieval process is based on the use of 10 IASI channels located in the $7.7 \mu \mathrm{m}$ spectral region that are mostly sensitive to $\mathrm{CH}_{4}$ and, as all infrared channels, to atmospheric temperature. Observations made in the microwave by the AMSU instrument, flying with IASI onboard MetOp-A (both instruments are synchronized), are also sensitive to temperature, but are insensitive to $\mathrm{CH}_{4}$. Thus, combining IASI and AMSU allows separating the two signals. The retrieval scheme, initially developed to retrieve $\mathrm{CO}_{2}$ from thermal infrared sounders (Chédin et al., 2003; Crevoisier et al., 2009b), is based upon a nonlinear regression inverse radiative transfer model using multilayer perceptrons. Given that, since the beginning of 2009, AMSU channel 7 has started to degrade and its noise now exceeds specifications, precluding any further use, AMSU 8 has replaced AMSU 7 in the retrieval process described in Crevoisier et al. (2009a).

In this work, potential radiative systematic biases existing between simulations used to train the networks and observations are computed for each channel by averaging, over the first three years of operation (July 2007-June 2010), the differences between simulations and collocated (in time and 
space) satellite observations. The simulations are performed using the 4A/OP-2009 forward model (Scott and Chédin, 1981; http://www.noveltis.net/4AOP/), which is based on the updated 2009 version of the GEISA spectroscopic database (available at http://ether.ipsl.jussieu.fr/) (Jacquinet-Husson et al., 2011), and radiosonde measurements from the Analyzed RadioSoundings Archive database (available at http: //ara.abct.lmd.polytechnique.fr/) as inputs.

Because of the lesser variability of the atmospheric temperature profiles in the tropics compared to higher latitudes, the decorrelation between temperature and methane signals in the observations is easier to do in the tropical belt, yielding a better precision there. We thus restrict our study to latitudes between $20^{\circ} \mathrm{N}$ to $20^{\circ} \mathrm{S}$. The extension to higher latitudes is currently under study. The retrieved $\mathrm{CH}_{4}$ integrated columns are weighted to the tropical mid-troposphere with peak sensitivity at about $230 \mathrm{hPa}(\sim 11 \mathrm{~km})$, half the peak sensitivity at 100 and $500 \mathrm{hPa}(\sim 6$ and $16 \mathrm{~km})$, and no sensitivity to the surface. Retrievals are performed over land and sea, night and day, at 09:30/21:30 LT.

In the absence of observed global maps of tropospheric $\mathrm{CH}_{4}$, one of the first ways of quantifying the dispersion of the retrievals is to determine the standard deviation of each monthly $5^{\circ} \times 5^{\circ}$ box item sample. As explained in Chédin et al. (2003) and Crevoisier et al. (2009a), these standard deviations may tentatively be seen as resulting from the combination of the standard deviation of the method itself and of the standard deviation of the natural variability of $\mathrm{CH}_{4}\left(5^{\circ} \times 5^{\circ}\right.$, one month). The resulting estimated accuracy of the method comes to $18 \mathrm{ppbv}$; slightly higher than the $16 \mathrm{ppbv}$ given in Crevoisier et al. (2009b). This slight change comes from the replacement of AMSU 7 by AMSU 8 in the retrieval process and highlights the fact that the decorrelation between temperature and $\mathrm{CH}_{4}$ in the infrared radiance is harder to performe because AMSU 8 is not as suited as AMSU 7 to constraining tropospheric temperature. Initial results from the monitoring of IASI $\mathrm{CH}_{4}$ retrievals within the ECMWF Integrated Forecast System, as part of the MACC-II European project, tend to confirm these values (S. Massart, private communication, 2013).

\subsection{Aircraft data}

Very few measurements of $\mathrm{CH}_{4}$ are available in the midtroposphere, rendering the validation of satellite retrievals as well as model simulations in the mid-troposphere quite delicate. The Total Carbon Column Observing Network (TCCON) is a network of ground-based Fourier transform spectrometers recording direct solar spectra in the nearinfrared spectral region from which accurate and precise column-averaged abundances of $\mathrm{CH}_{4}$ can be derived. It thus provides an essential validation resource for the retrievals of total column of $\mathrm{CH}_{4}$ performed from shortwave-infrared observations. However, IASI gives access to a mid-tropospheric column, and direct comparison to TCCON total $\mathrm{CH}_{4}$ abun- dance is thus not straightforward. In the following, we will use measurements made by commercial aircraft in the framework of two programs that provide valuable information about $\mathrm{CH}_{4}$ variations in the middle troposphere: CONTRAIL (Comprehensive Observation Network for Trace gases by AIrLiner) and CARIBIC (Civil Aircraft for the Regular Investigation of the atmosphere Based on an Instrument Container). We will also use measurements performed during 5 HIPPO (HIAPER Pole-to-Pole Observations) campaigns.

The CONTRAIL project originates from regular in situ measurements of $\mathrm{CO}_{2}$ made by commercial airliners of Japan Airlines (JAL) between Japan and Australia since the mid1980s (Nakazawa et al., 1991; Matsueda et al., 2002; data available at http://gaw.kishou.go.jp/wdcgg.html). In November 2005, the National Institute for Environmental Studies (NIES), the Meteorological Research Institute (MRI), Tohoku University and Japan Airlines started a new phase of the JAL project called CONTRAIL, expanding the commercial aircraft measurement program to include regular JAL flights from Japan to Europe, North America and Asia and providing measurements of $\mathrm{CO}_{2}, \mathrm{CH}_{4}$ and $\mathrm{CO}$ (Machida et al., 2007, 2008; Matsueda et al., 2008; Sawa et al., 2008). The acquired air samples are returned to NIES within a day of the sampling, and the mixing ratios of various trace gases including $\mathrm{CH}_{4}$ are analyzed. The $\mathrm{CH}_{4}$ mixing ratio of each air sample is determined against the NIES-94 $\mathrm{CH}_{4}$ scale using a gas chromatograph (Agilent 5890, Agilent Technologies Inc.) equipped with a flame ionization detector (GCFID) (Tohjima et al., 2002; Machida et al., 2008). According to the results of the 2002-2007 WMO Round-Robin intercalibration (Zhou et al., 2009), NIES-94 scale is higher than NOAA/GMD scale by 3.5-4.6 ppbv in a range between 1750 and $1840 \mathrm{ppbv}$.

CARIBIC is a long-term atmospheric measurement program based on the use of a comprehensive scientific instrument package aboard a commercial passenger aircraft operated by Lufthansa (Brenninkmeijer et al., 2007). Its first operational phase was from 1999-2001. Since May 2005 the new, extended CARIBIC instrumentation package is employed once per month during regular passenger flights out of Germany to Asia, Africa, and North and South America. Both real-time measurements and air sample collection are performed. The air samples are analyzed for a large number of trace gases in several laboratories, including GC-FID analysis of $\mathrm{CH}_{4}$ (Schuck et al., 2009). $\mathrm{CH}_{4}$ data are reported on the NOAA/GMD scale, with a precision of $2.2 \mathrm{ppbv}$.

The HIPPO project is investigating the carbon cycle and greenhouse gases throughout various altitudes of the Western Hemisphere through the annual cycle. HIPPO is supported by the National Science Foundation (NSF) and its operations are managed by the Earth Observing Laboratory (EOL) of the National Center for Atmospheric Research (NCAR). Five missions took place from January 2009 to September 2011. They measured atmospheric constituents along transects from approximately pole-to-pole over the 


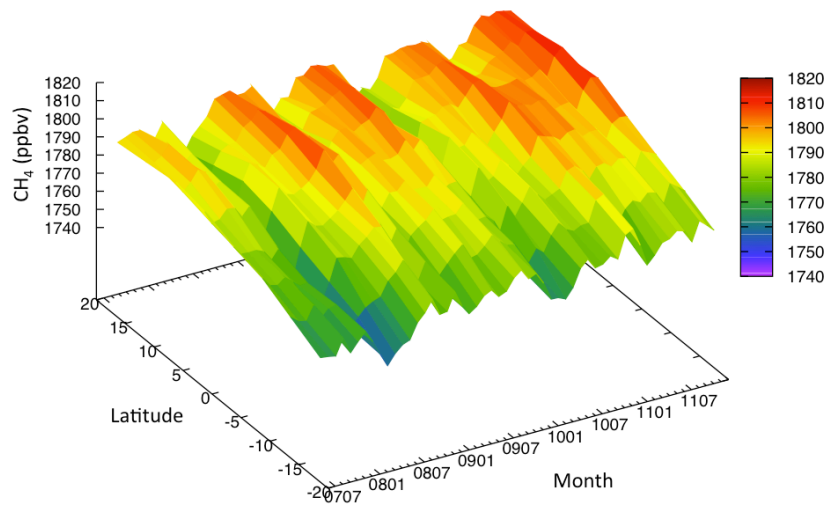

Fig. 1. Zonally averaged tropical distribution of methane in the mid-troposphere as retrieved from IASI from July 2007 to December 2011.

Pacific Ocean and flew hundreds of vertical profiles from the ocean/ice surface to as high as the tropopause, at five times during different seasons over the $3 \mathrm{yr}$ period. In the following, use is made of the 10 second merge product (Wofsy et al., 2012). HIPPO methane data are reported on the NOAA04 calibration scale.

While comparing IASI and aircraft observations, it must be kept in mind that CONTRAIL and CARIBIC $\mathrm{CH}_{4}$ is representative of methane at aircraft altitude $(\sim 11 \mathrm{~km})$, whereas IASI gives access to a mid-tropospheric integrated content.

\section{General features of mid-tropospheric $\mathrm{CH}_{4}$}

\subsection{Seasonal variations}

Figure 1 displays the zonally averaged tropical distribution of methane in the mid-troposphere as retrieved from IASI from July 2007 to December 2011. Several features are summarized in this figure that can be compared to the zonally averaged representation of the global distribution of methane in the marine boundary layer obtained from surface stations (e.g., Dlugokencky et al., 1994). Methane measured at the surface is generally characterized by low mixing ratios in local summer months, a combined effect of larger sources and stronger chemical losses, and large concentration in winter months, with a decreasing amplitude with latitudes from $\sim 40 \mathrm{ppbv}$ in the Northern Hemisphere (NH) to $\sim 20 \mathrm{ppbv}$ in the Southern Hemisphere (SH). IASI mid-tropospheric methane also displays strong seasonal variations in Fig. 1, with a more pronounced cycle in the northern than in the southern tropics. However, compared to surface data, the amplitude of the cycle is lower and varies from $\sim 25 \mathrm{ppbv}$ in the north to $\sim 15 \mathrm{ppbv}$ in the south.

In the northern tropics, the maximum is reached in November and the minimum in March-April. In the southern tropics, the seasonal variation is more complex. This may be attributed to the weak seasonal cycle of methane (a) Northern tropics

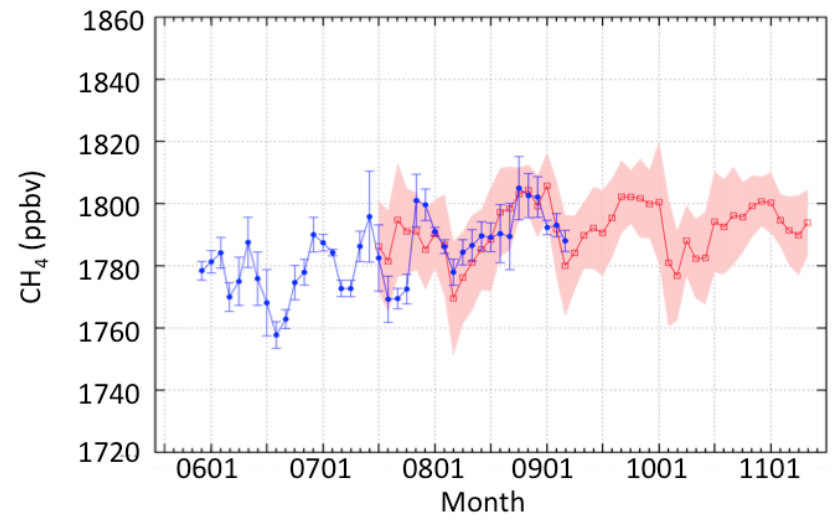

(b) Southern tropics

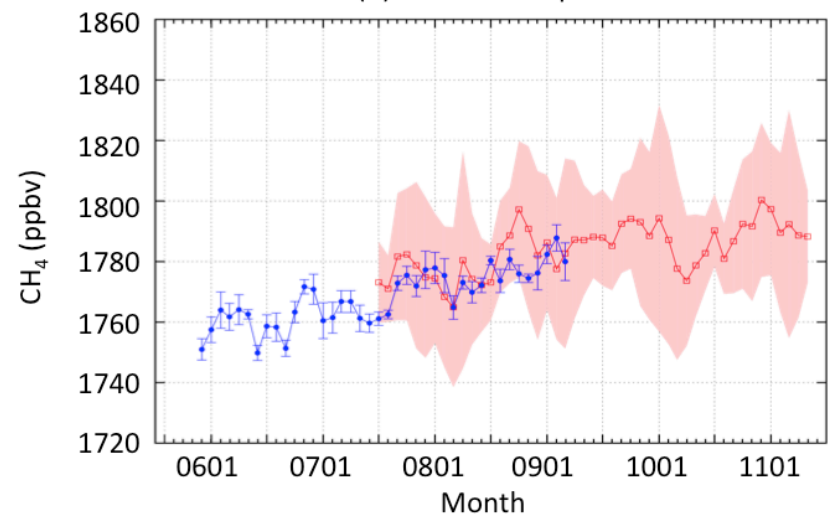

Fig. 2. Monthly evolution of mid-tropospheric methane measured by CONTRAIL (December 2006 to March 2009) at an altitude of $\sim 11 \mathrm{~km}$ (blue) and retrieved from IASI observations (since July 2007) for the 6-16 km range (red) in the northern (a) and southern (b) tropics between Japan and Australia. Standard deviations are shown as bars for CONTRAIL and as a red shaded area for IASI. A bias of $-9 \mathrm{ppbv}$ ( $3 \mathrm{ppbv}$ ) has been added to the CONTRAIL data in the Northern (Southern) Hemisphere.

in the SH that makes it sensitive to year-to-year fluctuations of upper-tropospheric winds at $\sim 200 \mathrm{hPa}$, which modulates the inter-hemispheric transport during ENSO phases (Prinn et al., 1992), yielding enhanced exchanges in DecemberMay during cold phases (as in 2007 and 2008), and a cancellation in the southern tropics of the summer minimum due to photochemical destruction of methane. Differences in phase and amplitude between surface measurements and IASI mid-tropospheric retrievals might be attributed to the time lag of the emitted methane when going from the surface to the upper-troposphere, combined with the seasonality of destruction by $\mathrm{OH}$, which mostly happens in the low to mid-troposphere between 700 and $500 \mathrm{hPa}$ (Spivakovsky et al., 2012).

Figure 2 shows the seasonal cycles in the northern and southern tropics measured by CONTRAIL and retrieved from IASI. Use is made of CONTRAIL flights 
between Japan and Australia from December 2005 to March 2009. IASI $\mathrm{CH}_{4}$ retrievals have been averaged over a $20^{\circ}$ longitudinal band centered on the flight tracks to get enough data. To ease the comparison a bias of $-9 \mathrm{ppbv}$ ( 3 ppbv) has been added to CONTRAIL data in the northern (southern) tropics. IASI and CONTRAIL cycles agree quite well for the period July 2007-March 2009 when both data are available. This is particularly true in the Northern Hemisphere, where the seasonal cycle is well defined. The amplitudes of CONTRAIL and IASI cycles are in good agreement with each other: about $25 \mathrm{ppbv}$ in the northern tropics and $15 \mathrm{ppbv}$ in the southern tropics. In the southern tropics, there seems to be an overestimation of IASI $\mathrm{CH}_{4}$ compared to CONTRAIL in August-October 2008. However, such high values of methane are not seen for the other years and seem to be specific to 2008. CONTRAIL data lie in the monthly standard deviation of IASI data computed along the flight tracks (red shaded area in Fig. 2).

\subsection{Latitudinal variations}

A clear interhemispheric variation of mid-tropospheric methane is observed by IASI with a north to south decrease of about $30 \mathrm{ppbv}$ between $20^{\circ} \mathrm{N}$ and $20^{\circ} \mathrm{S}$. As stated in Crevoisier et al. (2009a), this is in excellent agreement with aircraft measurements performed over a few months in 1993 at $10-11 \mathrm{~km}$, which corresponds to the peak of sensitivity of IASI in the channels selected to perform the retrievals, but is lower by more than a factor of 2 when compared to the gradient estimated from surface measurements, highlighting the influence of the proximity of emissions to the measurements and vertical mixing. Methane is well mixed in the southern tropics, while a gradient persists with methane regularly increasing with latitude in the northern tropics.

IASI mid-tropospheric $\mathrm{CH}_{4}$ is now compared with $\mathrm{CH}_{4}$ CARIBIC aircraft measurements made at $\sim 11 \mathrm{~km}$ over the African continent during 13 flights spanning the period March 2009-March 2011. Figure 3 shows the daily retrieved IASI $\mathrm{CH}_{4}$ (two to three orbits per day in the region of interest) together with the measured CARIBIC $\mathrm{CH}_{4}$ (two flights per month, except for November 2010, for which a single flight is available) for 6 consecutive months between November 2010 and March 2011. Differences in the spatial coverage and lack of retrievals because of cloudiness render the comparison between both datasets difficult. Nonetheless, the general features of methane appear to be consistent between IASI and CARIBIC: lower methane in the south than in the north, with high values of methane localized in a region between $5^{\circ} \mathrm{S}$ and $10^{\circ} \mathrm{N}$, where large wetland emissions (e.g., Bergamaschi et al., 2007) that are upvected in the mid-troposphere can be found. The general agreement between both datasets is better seen with the monthly averaged $\mathrm{CH}_{4}$ retrieved from IASI that is also plotted in Fig. 3. In particular, the location of high values of wetland-emitted methane is shown to vary in latitude around the Equator: in
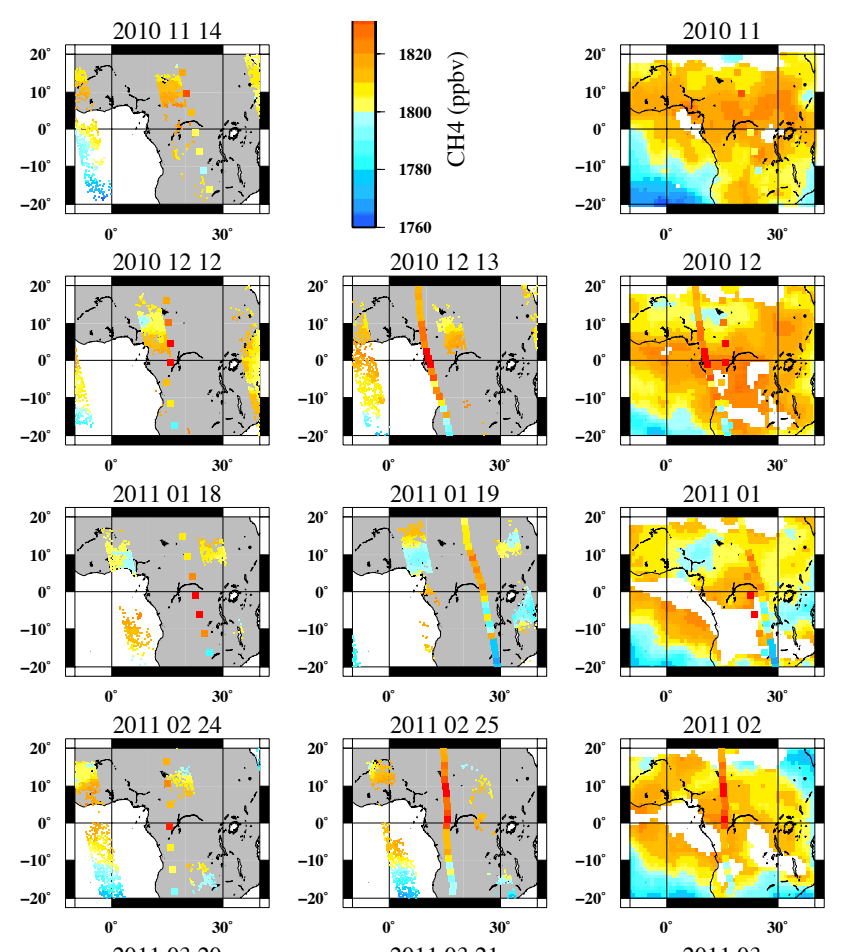

20110225
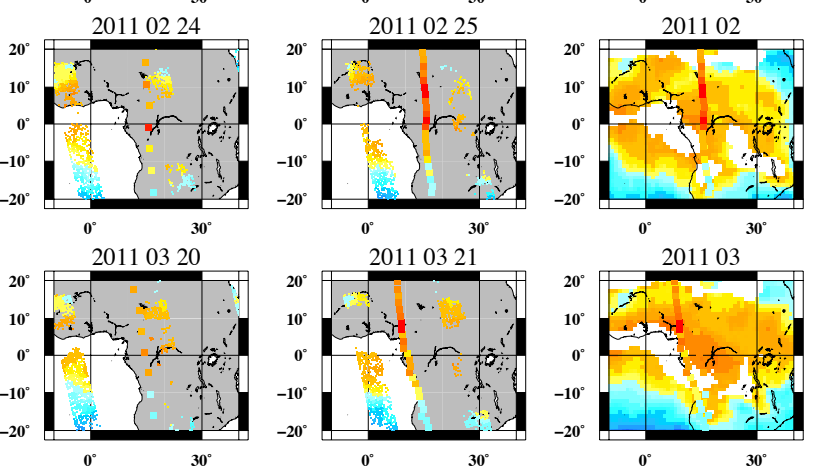

Fig. 3. Maps of daily IASI methane (first and second column) for the 7 days when CARIBIC measurements were performed between November 2010 and March 2011, and maps of monthly IASI methane (third column) for the same months. CARIBIC methane is shown as squares on each map.

December, $\mathrm{CH}_{4}$ is higher ( $\left.\sim 1820 \mathrm{ppbv}\right)$ between $10^{\circ} \mathrm{N}$ and the Equator, whereas in February-March, the highest concentrations ( $\sim 1810 \mathrm{ppbv})$ are found between the Equator and $10^{\circ} \mathrm{S}$. This variation is in good agreement with CARIBIC features, even if higher values are measured by the aircraft (up to $1880 \mathrm{ppbv}$ ) than retrieved by IASI. This may be due to the fact that the aircraft measure methane at one altitude, whereas IASI retrievals integrate methane over $6-16 \mathrm{~km}$.

The latitudinal variations of CARIBIC and monthly IASI methane are plotted in Fig. 4, together with the associated standard deviation of IASI retrievals. For this figure, monthly $1^{\circ} \times 1^{\circ}$ IASI fields have been collocated with CARIBIC tracks. Once more, both IASI and CARIBIC display similar variations and the aircraft data stay within the monthly standard deviation (light-blue shaded area in Fig. 4) retrieved from IASI with the two exceptions of very high values measured locally on 12 December 2010 and 18 January 2011. These two days illustrate the high variability of mid-tropospheric methane that is particularly seen on the 
(a)

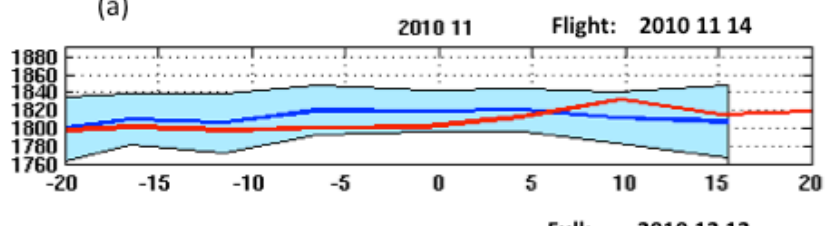

(b)

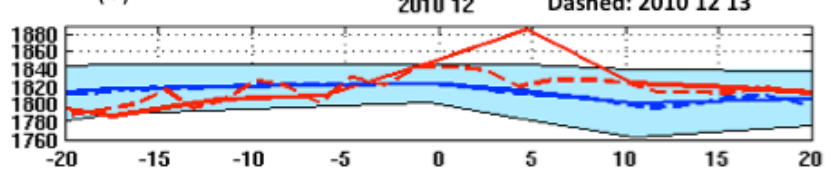

Full: 20110118

(c)

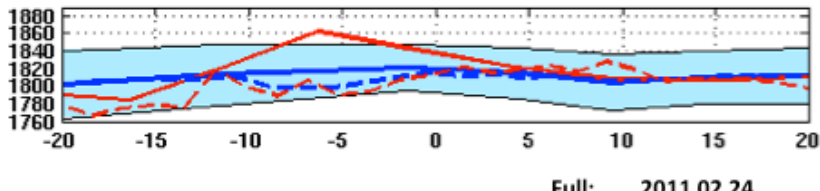

(d)
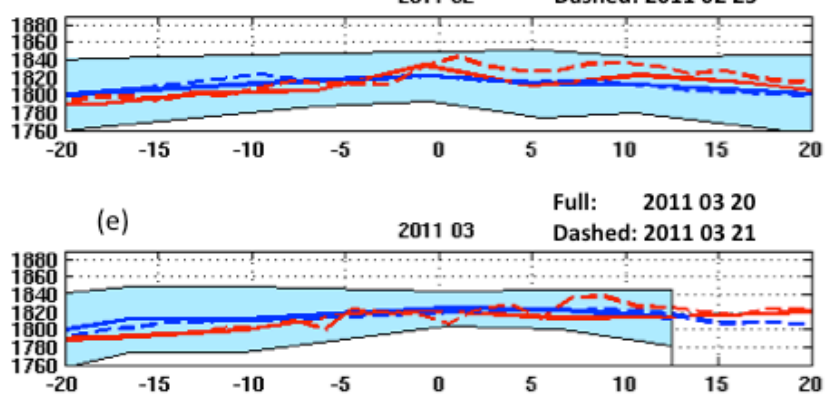

Fig. 4. Latitudinal variations of $\mathrm{CH}_{4}$ as measured by CARIBIC (red) and as retrieved by IASI (blue) between November 2010 and March $2011.1^{\circ} \times 1^{\circ}$ monthly IASI $\mathrm{CH}_{4}$ have been collocated with CARIBIC measurements. The blue shaded area gives the IASI monthly standard deviation along the aircraft tracks. With the exception of November 2010 (one flight only), the full line corresponds to the first flight of the month, and the dashed line to the return flight on the following day.

two CARIBIC flights performed on 18 and 19 January 2011 (Fig. 4c): between $10^{\circ} \mathrm{S}$ and $5^{\circ} \mathrm{S}$, a difference of more than $60 \mathrm{ppbv}$ is observed in methane between the two flights. This difference is consistent with the spatial variability of IASI $\mathrm{CH}_{4}$ in January displayed in Fig. 3 (third line): low values of methane ( $\sim 1780 \mathrm{ppbv})$ are well seen for this month (bluish colors) east of $28^{\circ} \mathrm{E}$, between $10^{\circ} \mathrm{S}$ and the Equator, where the flight of 19 January took place, whereas high values of methane ( $\sim 1815 \mathrm{ppbv}$, yellowish colors) are located west of this longitude, where the flight of 18 January took place. Such a structure is in agreement with wind patterns, which displays a positive (negative) gyre east (west) of this longitude, creating two regions of respectively high and low concentrations of methane. However, due to persistent cloudiness, the regions where the highest values of $\mathrm{CH}_{4}$ are measured by CARIBIC on 18 January 2011 are not seen by IASI. This explains the discrepancy in the latitudinal varia-

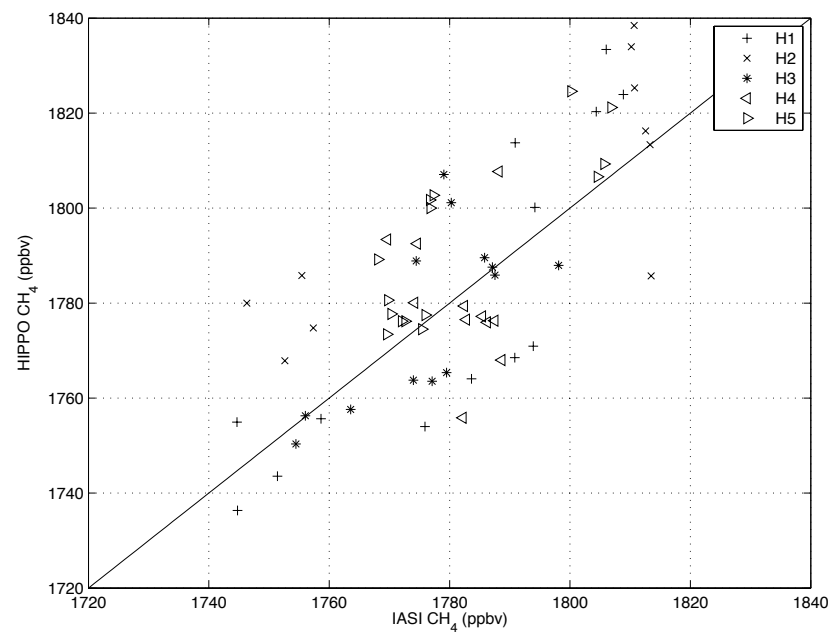

Fig. 5. HIPPO $\mathrm{CH}_{4}$ against IASI mid-tropospheric $\mathrm{CH}_{4}$. Symbols correspond to the 5 HIPPO missions (H1 to H5). For both datasets, $\mathrm{CH}_{4}$ individual measurements/retrievals have been averaged over $1^{\circ} \times 1^{\circ}$ boxes and then collocated in space for each day of the HIPPO missions.

tions given by IASI and CARIBIC in Fig. $4 \mathrm{c}$ for the 18 of January (full lines), whereas the agreement is quite good for 19 January (dashed lines). Differences in the space and time coverage, as well as in the vertical coverage can also explain the large discrepancy found for 12 December around $5^{\circ} \mathrm{N}$.

More quantitatively, the consistency between IASI and CARIBIC methane can be evaluated by averaging daily IASI $\mathrm{CH}_{4}$ in a $4^{\circ} \times 4^{\circ}$ box (to get enough collocations) centered on the measurements performed during the 13 CARIBIC flights. This comparison yields a bias between IASI and CARIBIC of $7.2 \mathrm{ppbv}$ with a standard deviation of $13.1 \mathrm{ppbv}$. The mean standard deviation of IASI retrievals in the $4^{\circ} \times 4^{\circ}$ boxes is $18 \mathrm{ppbv}$. We have checked that these values show negligible latitudinal and time variations. This statistical consistency between IASI and CARIBIC methane is also confirmed when comparing IASI and HIPPO $\mathrm{CH}_{4}$. To compare both datasets, individual HIPPO measurements performed between 6 and $12 \mathrm{~km}$ (altitude range corresponding to IASI vertical sensitivity to $\mathrm{CH}_{4}$ ) and IASI retrievals of methane are averaged in $1^{\circ} \times 1^{\circ}$ boxes for each day of the five HIPPO missions that took place in January 2009 (HIPPO 1), October-November 2009 (HIPPO 2), May-April 2010 (HIPPO 3), June-July 2011(HIPPO 4) and AugustSeptember 2011 (HIPPO 5). The scatter plot of HIPPO $\mathrm{CH}_{4}$ vs. IASI $\mathrm{CH}_{4}$ for the resulting 63 collocated points is shown in Fig. 5. The comparison gives a bias of $5.1 \mathrm{ppbv}$ and a standard deviation of $16.3 \mathrm{ppbv}$.

\section{Discussion}

A striking feature displayed in Fig. 1 and 2 is the increase of mid-tropospheric methane from 2007 to 2011, in agreement 
(a)

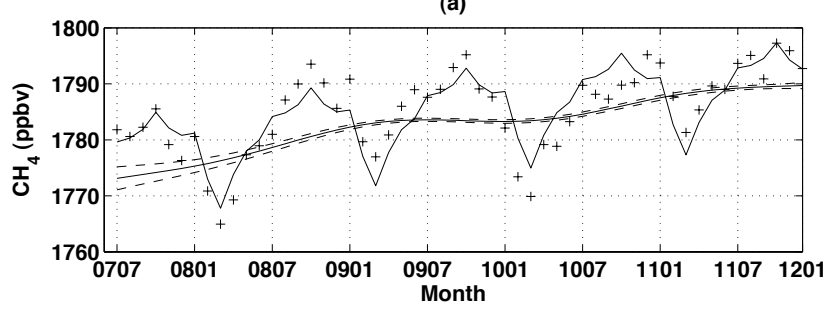

(b)

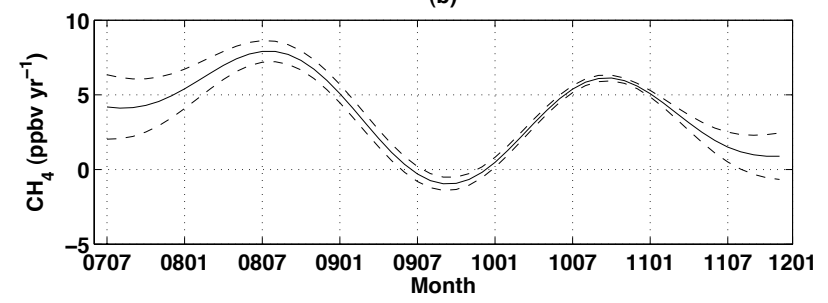

Fig. 6. (a) Monthly mean of IASI $\mathrm{CH}_{4}$ in the whole tropical region (crosses), fitted with a polynomial trend and 4 harmonics for the period July 2007 to December 2011. Also shown is the deseasonalized trend with \pm 1 standard deviation as dashed lines. (b) Instantaneous growth rate for globally averaged atmospheric $\mathrm{CH}_{4}$ (solid line) and \pm 1 standard deviation (dashed lines). The growth rate is the timederivative of the deseasonalized trend in (a).

with the renewed growth of methane measured at the surface since the end of 2006 (Rigby et al., 2008; Dlugokencky et al., 2009, hereafter referred to as R08 and D09 respectively). To investigate this increase in the mid-tropospheric methane burden, we use the sum of a quadratic polynomial and a series of four harmonics to represent the averaged long-term trend and the averaged seasonal cycle of methane, respectively. The differences between the fitting curve and the data (the residuals) are smoothed by applying a low-pass filter to account for interannual variations in the trend. The result is added to the quadratic polynomial to obtain a deseasonalized trend function (Duglokencky et al., 1994).

Figure 6a shows the fitted methane cycle estimated from IASI data over the IASI period (July 2007 to December 2011) for the entire tropical region. Also shown are the deseasonalized trend function and its associated standard deviation. The growth rate of methane given by the derivative of the deseasonalized trend function is plotted in Fig. 6b. An increase of methane in the mid-troposphere in the tropical region is clearly seen in this figure, with the highest increase rate in 2007-2008. Unfortunately, the beginning of the increase (end of 2006-beginning of 2007) is missed by IASI, which was declared operational in July 2007. In the following years, the rate of increase of methane appears to be decreasing, with an average increase of $\sim 2 \mathrm{ppbv} \mathrm{yr}^{-1}$ in 2009 and 2011 and of $\sim 5 \mathrm{ppbv} \mathrm{yr}^{-1}$ in 2010.

Figure 7 shows the latitudinal and temporal variations of the growth rate of methane obtained from IASI and from the GLOBALVIEW-CH 4 (2009) surface stations located in the tropical band for the period 2007-2010. It should be kept
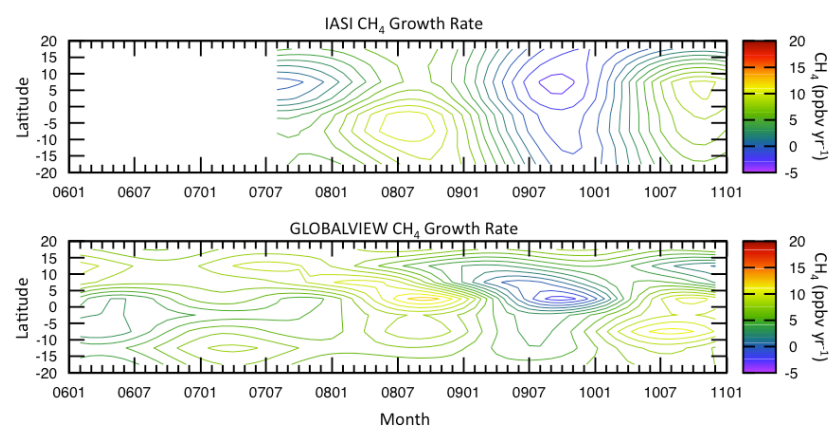

Fig. 7. Growth rate of $\mathrm{CH}_{4}$ as retrieved from IASI (top) and as derived from the GLOBALVIEW- $\mathrm{CH}_{4}$ (2009) surface stations (bottom) from January 2006 to December 2010.

in mind that IASI provides a homogeneous coverage of the tropical band, whereas surface measurements are only available at $\sim 20$ stations in this band. Nonetheless, growth rates measured at the surface and in the mid-troposphere are similar, with a good match both in terms of temporal and geographical locations of positive and negative growth rates. According to Fig. 7, methane has been increasing in both the northern and southern tropics, but there are differences in the intensity of the growth rate. Annual increases of methane are given in Table 1 together with their standard deviations. They are determined for each year by taking the difference between January in one year and January in the next year on the deseasonalized trend curve in Fig. 6a. Since only half of 2007 is available from IASI, the annual increase for this year is based on the extrapolation of the fit to the other half of the year by applying the coefficients derived from the $4.5 \mathrm{yr}$ of IASI to the first six months of 2007. The resulting standard deviation for 2007 is thus higher than for the years fully constrained by IASI data. The values inferred from IASI retrievals for $2007\left(9.5 \pm 2.8 \mathrm{ppbv} \mathrm{yr}^{-1}\right)$ and 2008 $\left(6.9 \pm 1.2 \mathrm{ppbv} \mathrm{yr}^{-1}\right)$ are in good agreement with the growth rates reported by D09 and R08.

As seen in Fig. 7, according to IASI, the increase in the southern tropics was larger than in the northern tropics for $2007\left(10.7 \pm 2.5\right.$ vs. $\left.8.2 \pm 1.8 \mathrm{ppbv} \mathrm{yr}^{-1}\right)$ and 2008 $\left(7.9 \pm 1.2\right.$ vs. $\left.6.0 \pm 1.2 \mathrm{ppbv} \mathrm{yr}^{-1}\right)$. D09 did report a larger increase of atmospheric methane in the $\mathrm{SH}$ than in the $\mathrm{NH}$ for 2007, as seen in Fig. 6, with a zonally averaged SH trend of $9.2 \pm 0.3 \mathrm{ppbv} \mathrm{yr}^{-1}$ compared to a zonally averaged $\mathrm{NH}$ trend of $7.3 \pm 1.3 \mathrm{ppbv} \mathrm{yr}^{-1}$. This may again be due to the enhanced transport from the $\mathrm{NH}$ to the $\mathrm{SH}$ in La Niña years (Prinn et al., 1992). According to R08, stations located in the southern tropics experienced a higher increase than stations located at higher southern latitudes, which might explain the highest increase we find in the EQ: $20^{\circ} \mathrm{S}$ band compared to the SH increase reported by D09. For 2008 these authors found the largest increase at low northern latitudes with a value of $8.1 \pm 1.6 \mathrm{ppbv} \mathrm{yr}^{-1}$, for a slowing global increase of $4.4 \pm 0.6 \mathrm{ppbv} \mathrm{yr}^{-1}$, whereas IASI estimates seem to indicate 


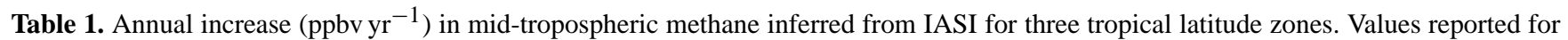
the Northern and Southern Hemisphere (NH and SH) by Dlugokencky et al. (2009) are also given. For 2007 only half of the year is available from IASI. ${ }^{+}$This value is attributed to low northern latitudes.

\begin{tabular}{llllll}
\hline & \multicolumn{3}{c}{ IASI } & \multicolumn{2}{l}{ Dlugokencky et al. (2009) } \\
\hline Year & $20^{\circ} \mathrm{N}: 20^{\circ} \mathrm{S}$ & $20^{\circ} \mathrm{N}: \mathrm{EQ}$ & $\mathrm{EQ}: 20^{\circ} \mathrm{S}$ & $\mathrm{NH}$ & $\mathrm{SH}$ \\
\hline 2007 & $9.5 \pm 2.8$ & $8.2 \pm 1.8$ & $10.7 \pm 2.5$ & $7.3 \pm 1.3$ & $9.2 \pm 0.3$ \\
2008 & $6.9 \pm 1.3$ & $6.0 \pm 1.2$ & $7.9 \pm 1.2$ & $8.1 \pm 1.6^{+}$ & \\
2009 & $1.0 \pm 0.8$ & $-0.3 \pm 0.5$ & $2.3 \pm 0.7$ & & \\
2010 & $4.2 \pm 0.9$ & $3.6 \pm 0.5$ & $4.8 \pm 0.8$ & & \\
2011 & $2.2 \pm 0.7$ & $2.5 \pm 0.7$ & $1.8 \pm 0.7$ & & \\
\hline
\end{tabular}

a larger increase in the southern tropics. This disagreement on the exact location of the highest increase of methane in 2008 might be due to the different spatial coverage of both datasets, with 1 to 2 surface stations located in each $5^{\circ}$ latitude band, while IASI coverage is more homogeneous. According to IASI observations, the increase of methane seems to continue in the tropics but at a slower rate with an average of $1.0 \pm 0.5 \mathrm{ppbv} \mathrm{yr}^{-1}$ in $2009,4.2 \pm 0.5 \mathrm{ppbv} \mathrm{yr}^{-1}$ in 2010 and $2.2 \pm 0.7 \mathrm{ppbv} \mathrm{yr}^{-1}$ in 2011 .

Methane variability can be attributed to variations in the surface emissions or in the strength of $\mathrm{OH}$ sink. R08 have found a large but uncertain change in $\mathrm{OH}$ concentrations in 2007 as compared to $2006(-4 \pm 14 \%)$. D09 have suggested a slight change in $\mathrm{OH}$, but a significant contribution of emissions at high latitudes in 2007, and an increase of methane emission from tropical wetlands due to enhanced La Niña precipitation in 2007 and 2008. Such a hypothesis has been confirmed by Bousquet et al. (2011) by using both atmospheric inversions and a process-based model of methane emissions by natural wetland ecosystems. As seen in Fig. 6, IASI data suggests a slowing down of the increase in 2009-2011. This result thus indicates either an increase of the destruction of methane by $\mathrm{OH}$ or a decrease in methane surface emissions in the tropics (predominantly wetlands and biomass burning) as compared to previous years. The analysis of ECMWF precipitation fields reveals that precipitation has continuously decreased in wetland tropical regions from 2009 to 2011. In particular, the total rain fall in 2010 reached a value similar to that of 2007 . More specifically, a severe drought happened in Amazonia in 2010 due to a particularly high value of the Atlantic Multidecadal Oscillation (Lewis et al., 2011). Moreover, our analysis of MODIS burned area (Roy et al., 2008) shows (i) no significant change in fires, and thus in biomass burning $\mathrm{CH}_{4}$ emissions, in the tropical region over 2007-2009, and (ii) a sharp increase of fire in 2010 (Thonat et al., 2012), which might explain part of the increase of methane seen in the second half of 2010 by IASI since the fire season extends from July to October in most of the southern regions. These results seem to confirm that tropical wetland emissions driven by higher than average, although decreasing after 2008, precipitation are one of the main drivers of the 2007-2008 strong increase and of the less pronounced increase of methane suggested by IASI observations in the following years.

\section{Conclusions}

Observations made in infrared by IASI have been used to derive the distribution of methane in the mid-troposphere $(6-16 \mathrm{~km})$, in the tropics from July 2007 to December 2011. A strong seasonal cycle of $25 \mathrm{ppbv}$ is observed in the northern tropics, with a maximum (minimum) in November (March-April). The cycle observed in the southern tropics is more complex, with an amplitude of $\sim 15$ ppbv. Comparisons performed with aircraft measurements from the CONTRAIL, CARIBIC and HIPPO programs show that methane fields derived from IASI observations agree well with the features of in situ measurements of mid-tropospheric methane in terms of seasonality, amplitude and latitudinal variations. The latitudinal and temporal variations of the methane growth rate measured by IASI are also in good agreement with those measured at the surface.

According to IASI observations, methane increased by $19.1 \pm 3.0 \mathrm{ppbv}$ over the period 2007-2011, with a decreasing annual growth rate from $9.5 \pm 2.8 \mathrm{ppbv} \mathrm{yr}^{-1}$ in 2007 , in agreement with the surface increase rate, to $2.2 \pm 0.7 \mathrm{ppbv} \mathrm{yr}^{-1}$ in 2011. A higher rate of increase is found in the southern tropics than in the northern tropics during 2007 and 2008, possibly due to enhanced interhemispheric exchange characteristic of such La Niña years (Prinn et al., 1992).

Assuming that the recent increase of atmospheric methane in the tropics is mostly due to an increase in wetland emission, IASI retrievals would indicate a decrease of methane emission from wetlands for 2009-2011. Such a hypothesis is supported by the continued decrease in precipitation over these years in wetland tropical regions indicated by ECMWF precipitation fields, and small changes in tropical biomass burning emission for 2008-2009 indicated by MODIS burned area. Higher values of methane observed in 
2010 in the southern tropics might be attributed to intense biomass burnings that took place in the southern tropics.

Only continuous measurements of methane from a variety of instruments (at the surface, airborne and spaceborne) will help to better understand atmospheric methane budget and its evolution. The results presented here show that IASI can provide a powerful constraint on the monitoring and understanding of atmospheric methane burden. With a second IASI instrument having been launched onboard MetOp-B in September 2012, and the scheduled launch of a third IASI instrument onboard MetOp-C in 2017, more than $20 \mathrm{yr}$ of observations of mid-tropospheric methane will be available for climate studies.

Acknowledgements. This research has received funding from the European Union's Seventh Framework Programme (FP7/20072013) under Grant Agreements no. 218793 and 283576 (MACC and MACC-II projects) and from the ESA GHG-CCI project. We particularly wish to thank Cathy Boone and the Ether Thematic Center team for their help in getting IASI data, which are received through the EUMETCast near-real-time data distribution service. Thanks are due to ECMWF for making their forecasts and reanalysis available through the ECMWF data server http://www.ecmwf.int/. Calculations were performed at IDRIS, the computer centre of CNRS, and at ClimServ, the data and computer centre of IPSL.

Edited by: A. Richter

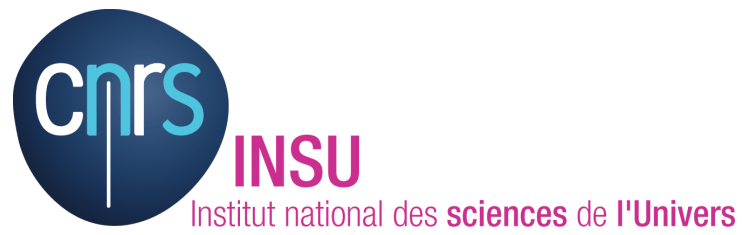

The publication of this article is financed by CNRS-INSU.

\section{References}

Bergamaschi, P., Frankenberg, C., Meirink, J. F., Krol, M., Dentener, F., Wagner, T., Platt, U., Kaplan, J. O., Körner, S., Heimann, M., Dlugokencky, E. J., and Goede, A.: Satellite chartography of atmospheric methane from SCIAMACHY on board ENVISAT: 2. Evaluation based on inverse model simulations, J. Geophys. Res., 112, D02304, doi:10.1029/2006JD007268, 2007.

Bousquet, P., Ciais, P., Miller, J. B., Dlugokencky, E. J., Hauglustaine, D. A., Prigent, C., Van der Werf, G. R., Peylin, P., Brunke, E.-G., Carouge, C., Langenfelds, R. L., Lathière, J., Papa, F., Ramonet, M., Schmidt, M., Steele, L. P., Tyler, S. C., and White, J.: Contribution of anthropogenic and natural sources to the variability of atmospheric methane, Nature, 443, 439-443, doi:10.1038/nature05132, 2006.

Bousquet, P., Ringeval, B., Pison, I., Dlugokencky, E. J., Brunke, E.G., Carouge, C., Chevallier, F., Fortems-Cheiney, A., Frankenberg, C., Hauglustaine, D. A., Krummel, P. B., Langenfelds, R.
L., Ramonet, M., Schmidt, M., Steele, L. P., Szopa, S., Yver, C., Viovy, N., and Ciais, P.: Source attribution of the changes in atmospheric methane for 2006-2008, Atmos. Chem. Phys., 11, 3689-3700, doi:10.5194/acp-11-3689-2011, 2011.

Brenninkmeijer, C. A. M., Crutzen, P., Boumard, F., Dauer, T., Dix, B., Ebinghaus, R., Filippi, D., Fischer, H., Franke, H., Frie $\beta$, U., Heintzenberg, J., Helleis, F., Hermann, M., Kock, H. H., Koeppel, C., Lelieveld, J., Leuenberger, M., Martinsson, B. G., Miemczyk, S., Moret, H. P., Nguyen, H. N., Nyfeler, P., Oram, D., O’Sullivan, D., Penkett, S., Platt, U., Pupek, M., Ramonet, M., Randa, B., Reichelt, M., Rhee, T. S., Rohwer, J., Rosenfeld, K., Scharffe, D., Schlager, H., Schumann, U., Slemr, F., Sprung, D., Stock, P., Thaler, R., Valentino, F., van Velthoven, P., Waibel, A., Wandel, A., Waschitschek, K., Wiedensohler, A., Xueref-Remy, I., Zahn, A., Zech, U., and Ziereis, H.: Civil Aircraft for the regular investigation of the atmosphere based on an instrumented container: The new CARIBIC system, Atmos. Chem. Phys., 7, 4953-4976, doi:10.5194/acp-7-4953-2007, 2007.

Chédin, A., Serrar, S., Scott, N. A., Crevoisier, C., and Armante, R.: First global measurement of midtropospheric $\mathrm{CO}_{2}$ from NOAA polar satellites: Tropical zone, J. Geophys. Res., 108, 4581, doi:10.1029/2003JD003439, 2003.

Crevoisier, C., Chédin, A., Matsueda, H., Machida, T., Armante, R. and Scott, N. A.: First year of upper tropospheric integrated content of $\mathrm{CO}_{2}$ from IASI hyperspectral infrared observations, Atmos. Chem. Phys., 9, 4797-4810, doi:10.5194/acp-9-4797-2009, 2009a.

Crevoisier, C., Nobileau, D., Fiore, A., Armante, R., Chédin, A., and Scott, N. A.: Tropospheric methane in the tropics - first year from IASI hyperspectral infrared observations, Atmos. Chem. Phys., 9, 6337-6350, doi:10.5194/acp-9-6337-2009, 2009 b.

Cunnold, D. M., Steele, L. P., Fraser, P. J., Simmonds, P. G., Prinn, R. G., Weiss, R. F., Porter, L. W., O'Doherty, S., Langenfelds, R. L., Krummel, P. B., Wang, H. J., Emmons, L., Tie, X. X., and Dlugokencky, E. J.: In situ measurements of atmospheric methane at GAGE/AGAGE sites during 1985-2000 and resulting source inferences, J. Geophys. Res., 107, 4225, doi:10.1029/2001JD001226, 2002.

Denman, K. L., Brasseur, G., Chidthaisong, A., Ciais, P., Cox, P. M., Dickinson, R. E., Hauglustaine, D., Heinze, C., Holland, E., Jacob, D., Lohmann, U., Ramachandran, S., da Silva Dias, P. L., Wofsy S. C., and Zhang, X.: Couplings Between Changes in the Climate System and Biogeochemistry, in: Climate Change 2007: The Physical Science Basis. Contribution of Working Group I to the Fourth Assessment Report of the Intergovernmental Panel on Climate Change, edited by: Solomon, S., Qin, D., Manning, M., Chen, Z., Marquis, M., Averyt, K. B., Tignor, M., and Miller, H. L., Cambridge University Press, Cambridge, UK and New York, NY, USA, 2007.

Dentener, F., Peters, W., Krol, M., van Weele, M., Bergamaschi, P., and Lelieveld, J.: Interannual variability and trend of $\mathrm{CH}_{4}$ lifetime as a measure for $\mathrm{OH}$ changes in the 1979-1993 time period, J. Geophys. Res., 108, 4442, doi:10.1029/2002JD002916, 2003.

Dlugokencky, E. J., Steele, L., Lang, P., and Masarie, K. A.: The growth rate and distribution of atmospheric methane, J. Geophys. Res., 99, 17021-17043, 1994.

Dlugokencky, E. J., Houweling, S., Bruhwiler, L., Masarie, K. A., Lang, P. M., Miller, J. B., and Tans, P. P.: Atmospheric methane levels off: Temporary pause or a new steady-state?, Geophys. 
Res. Lett., 30, 1992, doi:10.1029/2003GL018126, 2003.

Dlugokencky, E. J., Bruhwiler, L., White, J. W. C., Emmons, L. K., Novelli, P. C., Montzka, S. A., Masarie, K. A., Lang, P. M., Crotwell, A. M., Miller, J. B., and Gatti, L. V.: Observational constraints on recent increases in the atmospheric $\mathrm{CH}_{4}$ burden, Geophys. Res. Lett., 36, L18803, doi:10.1029/2009GL039780, 2009.

Frankenberg, C., Aben, I., Bergamaschi, P., Dlugokencky, E. J., van Hees, R., Houweling, S., van der Meer, P., Snel, R., and Tol, P.: Global column-averaged methane mixing ratios from 2003 to 2009 as derived from SCIAMACHY: Trends and variability, J. Geophys. Res., 116, D04302, doi:10.1029/2010JD014849, 2011.

Fung, I., John, J., Lerner, J., Matthews, E., Prather, M., Steele, L., and Fraser, P.: Three-Dimensional Model Synthesis of the Global Methane Cycle, J. Geophys. Res., 96, 13033-13065, 1991.

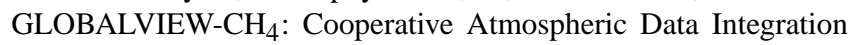
Project - Methane. CD-ROM, NOAA ESRL, Boulder, Colorado, also available on Internet via anonymous FTP to ftp.cmdl.noaa. gov, Path: ccg/ch4/GLOBALVIEW, 2009.

Hilton, F., Armante, R., August, T., Barnet, C., Bouchard, A., Camy-Peyret, C., Capelle, V., Clarisse, L., Clerbaux, C., Coheur, P.-F., Collard, A., Crevoisier, C., Dufour, G., and Edwards, D.: Faijan, F., Fourrié, N., Gambacorta, A., Goldberg, M., Guidard, V., Hurtmans, D., Illingworth, S., Jacquinet-Husson, N., Kerzenmacher, T., Klaes, D., Lavanant, L., Masiello, G., Matricardi, M., McNally, A., Newman, S., Pavelin, E., Payan, S., Péquignot, E., Peyridieu, S., Phulpin, T., Remedios, J., Schl"ussel, P., Serio, C., Strow, L., Stubenrauch, C., Taylor, J., Tobin, D., Wolf, W., and Zhou, D.: Hyperspectral Earth Observation from IASI: Five Years of Accomplishments, B. Am. Meteor. Soc., 93, 347-370, doi:10.1175/BAMS-D-11-00027.1, 2012.

IPCC: Climate change 2007: The physical science basis. Contribution of working group I to the fourth assessment report of the intergovernmental panel on climate change, Cambridge, UK and New York, USA, Cambridge University Press, 996 pp., 2007.

Langenfelds, R. L., Francey, R. J., Pak, B. C., Steele, L. P., Lloyd, J., Trudinger, C. M., and Allison, C. E. : Interannual growth rate variations of atmospheric $\mathrm{CO}_{2}$ and its $\delta^{13} \mathrm{C}, \mathrm{H}_{2}, \mathrm{CH}_{4}$, and $\mathrm{CO}$ between 1992 and 1999 linked to biomass burning, Global Biogeochem. Cy., 16, 1048, doi:10.1029/2001GB001466, 2002.

Lewis, S. L., Brando, P. M., Phillips, O. L., van der Heijden, G. M. F., and Nepstad, D.: The 2010 Amazon drought, Science, 331, p. 554, 2011.

Machida, T., Matsueda, H., and Sawa, Y.: A new JAL project: CONTRAIL - Comprehensive Observation Network for Trace gases by AIrLiner -, IGAC Newsletter, 37, 23-30, 2007.

Machida, T., Matsueda, H., Sawa, Y., Nakagawa, Y., Hirotani, K., Kondo, N., Goto, K., Nakazawa, T., Ishikawa, K., and Ogawa, T.: Worldwide measurements of atmospheric $\mathrm{CO}_{2}$ and other trace gas species using commercial airlines, J. Atmos. Oceanic. Technol. 25, 1744-1754, doi:10.1175/2008JTECHA1082.1, 2008.

Matsueda, H., Inoue, H., and Ishii, M.: Aircraft observation of carbon dioxide at $8-13 \mathrm{~km}$ altitude over the western Pacific from 1993 to 1999, Tellus B, 54, 1-21, 2002.

Matsueda, H., Machida, T., Sawa, Y., Nakagawa, Y., Hirotani, K., Ikeda, H., Kondo, N., and Goto, K.: Evaluation of atmospheric $\mathrm{CO}_{2}$ measurements from new flask air sampling of JAL airliner observation, Pap. Meteorolo. Geophys. 59, 1-17, 2008.
Matthews, E. and Fung, I.: Methane Emission From Natural Wetlands: Global Distribution, Area, and Environmental Characteristics of Sources, Global Biogeochem. Cy., 1, 61-86, 1987.

Mikaloff-Fletcher , S. E., Tans, P. P., Bruhwiler, L. M., Miller, J. B., and Heimann, M.: $\mathrm{CH}_{4}$ sources estimated from atmospheric observations of $\mathrm{CH}_{4}$ and its ${ }^{13} \mathrm{C} /{ }^{12} \mathrm{C}$ isotopic ratios: 1 . Inverse modeling of source processes, Global Biogeochem. Cy., 18, GB4004, doi:10.1029/2004GB002223, 2004.

Nakazawa, T., Miyashita, K., Aoki, S., and Tanaka, M.: Temporal and spatial variations of upper troposphere and lower stratospheric carbon dioxide, Tellus, 43B, 106-117, 1991.

Prinn, R., Cunnold, D., Simmonds, P., Alyea, F., Boldi, R., Crawford, A., Fraser, P., Gutzler, D., Hartley, D., Rosen, R.: Global Average Concentration and Trend for Hydroxyl Radicals Deduced From ALE/GAGE Trichloroethane (Methyl Chloroform) Data for 1978-1990, J. Geophys. Res., 97, 2445-2461, 1992.

Prinn, R. G., Huang, J., Weiss, R. F., Cunnold, D. M., Fraser, P. J., Simmonds, P. G., McCulloch, A., Harth, C., Reimann, S., Salameh, P., O’Doherty, S., Wang, R. H. J., Porter, L. W., Miller, B. R., and Krummel, P. B.: Evidence for variability of atmospheric hydroxyl radicals over the past quarter century, Geophys. Res. Lett., 32, L07809, doi:10.1029/2004GL022228, 2005.

Rigby, M., Prinn, R. G., Fraser, P. J., Simmonds, P. G, Langenfelds, R. L., Huang, J., Cunnold, D. M., Steele, L. P., Krummel, P. B., Weiss, R. F., O’Doherty, S., Salameh, P. K., Wang, H. J., Harth, C. M., Mühle, J., and Porter, L. W.: Renewed growth of atmospheric methane, Geophys. Res. Lett., 35, L22805, doi:10.1029/2008GL036037, 2008.

Ringeval, B., de Noblet-Ducoudré, N., Ciais, P., Bousquet, P., Prigent, C., Papa, F., and Rossow, W. B.: An attempt to quantify the impact of changes in wetland extent on methane emissions on the seasonal and interannual time scales, Global Biogeochem. Cy., 24, GB2003, doi:10.1029/2008GB003354, 2010.

Roy, D. P., Boschetti, L., Justice, C. O., and Ju, J.: The Collection 5 MODIS Burned Area Product - Global Evaluation by Comparison with the MODIS Active Fire Product, Remote Sens. Environ., 112, 3690-3707, 2008.

Sawa, Y., Machida, T., and Matsueda, H.: Seasonal variations of $\mathrm{CO}_{2}$ near the tropopause observed by commercial aircraft, J. Geophys. Res., 113, D23301, doi:10.1029/2008JD010568, 2008.

Schuck, T. J., Brenninkmeijer, C. A. M., Slemr, F., Xueref-Remy, I., and Zahn, A.: Greenhouse gas analysis of air samples collected onboard the CARIBIC passenger aircraft, Atmos. Meas. Tech., 2, 449-464, doi:10.5194/amt-2-449-2009, 2009.

Scott, N. A. and Chédin, A.: A fast line-by-line method for atmospheric absorption computations: The Automatized Atmospheric Absorption Atlas, J. Appl. Meteor., 20, 802-812, 1981.

Spivakovsky, C. M., Logan, J. A., Montzka, S. A., Balkanski, Y. J., Foreman-Fowler, M., Jones, D. B. A., Horowitz, L. W., Fusco, A. C., Brenninkmeijer, C. A. M., Prather, M. J., Wofsy, S. C., and McElroy, M. B.: Three-dimensional climatological distribution of tropospheric $\mathrm{OH}$ : Update and evaluation, J. Geophys. Res., 105, 8931-8980, doi:10.1029/1999JD901006, 2000.

Steele, L. P., Dlugokencky, E. J., Lang, P. M.,Tans, P. P., Martin, R. C., and Masarie, K. A.: Slowing down of the global accumulation of atmospheric methane during the 1980s, Nature, 358, 313-316, 1992.

Terao, Y., Mukai, H., Nojiri, Y., Machida, T., Tohjima, Y., Saeki, T., and Maksyutov, S.: Interannual variability and trends in atmo- 
spheric methane over the western Pacific from 1994 to 2010, J. Geophys. Res., 116, D14303, doi:10.1029/2010JD015467, 2011.

Thonat, T., Crevoisier, C. Scott, N. A., Chédin, A., Schuck, T., Armante, R., and Crépeau, L.: Retrieval of tropospheric CO column from hyperspectral infrared sounders - application to four years of Aqua/AIRS and MetOp-A/IASI, AMTD, 2012.

Tohjima, Y., Machida, T., Utiyama, M., Katsumoto, M., Fujinuma, Y., and Maksyutov, S.: Analysis and presentation of in situ atmospheric methane measurements from Cape Ochi-ishi and Hateruma Island, J. Geophys. Res., 107, 4148, doi:10.1029/2001JD001003, 2002.

Wofsy, S. C., Daube, B. C., Jimenez, R., Kort, E., Pittman, J. V., Park, S., Commane, R., Xiang, B., Santoni, G., Jacob, D., Fisher, J., Pickett-Heaps, C., Wang, H., Wecht, K., Wang, Q.-Q., Stephens, B. B., Shertz, S., Watt, A. S., Romashkin, P., Campos, T., Haggerty, J., Cooper, W. A., Rogers, D., Beaton, S., Hendershot, R., Elkins, J. W., Fahey, D. W., Gao, R. S., Moore, F., Montzka, S. A., Schwarz, J. P., Perring, A. E., Hurst, D., Miller, B. R., Sweeney, C., Oltmans, S., Nance, D., Hintsa, E., Dutton, G., Watts, L. A., Spackman, J. R., Rosenlof, K. H., Ray, E. A., Hall, B., Zondlo, M. A., Diao, M., Keeling, R., Bent, J., Atlas, E. L., Lueb, R., and Mahoney, M. J.: HIPPO Merged 10-second Meteorology, Atmospheric Chemistry, Aerosol Data (R_20121129). Carbon Dioxide Information Analysis Center, Oak Ridge National Laboratory, Oak Ridge, Tennessee, USA, http://dx.doi.org/ 10.3334/CDIAC/hippo_010 (Release 29 November 2012), 2012.
Worthy, D. E., Chan, J. E., Ishizawa, M., Chan, D., Poss, C., Dlugokencky, E. J., Maksyutov, S., and Levin, I.: Decreasing anthropogenic methane emissions in Europe and Siberia inferred from continuous carbon dioxide and methane observations at Alert, Canada, J. Geophys. Res., 114, D10301, doi:10.1029/2008JD011239, 2009.

Zhou, L. X., Kitis, D., and Tans, P. P.: Report of the Fourth WMO Round-Robin Reference Gas Intercomparison, 2002-2007, In Report of the 14th WMO/IAEA Meeting of Experts on Carbon Dioxide, Other Greenhouse Gases and Related Tracers Measurement Techniques, Helsinki, 10-13 September 2007, edited by Tuomas Laurila, WMO/GAW Report No. 186, 40-43, 2009. 